\title{
Терагерцовая система «накачка-зондирование» на Новосибирском ЛСЭ для измерения временной динамики релаксации в примесном полупроводнике
}

\author{
В.Д. Кукотенко ${ }^{1,2, *}$, Ю.Ю. Чопорова ${ }^{1,3}$, Н.Д. Осинцева ${ }^{1,3}$, \\ Р.Х. Жукавин ${ }^{4}$, К.А. Ковалевский ${ }^{4}$, Б.А. Князев ${ }^{1,3}$ \\ ${ }^{1}$ Институт ядерной физики Г. И. Будкера СО РАН \\ ${ }^{2}$ Новосибирский государственный технический университет \\ ${ }^{3}$ Новосибирский государственный университет \\ ${ }^{4}$ Институт физики микроструктур СО РАН \\ *E-mail: kukotenkovaleria@gmail.com
}

DOI: 10.31868/RFL2020.226-227

Полупроводники известны во всем мире своим широким спектром применения. Быстродействие детекторов на их основе определяется временами релаксации. Детекторы на основе германия с различными примесями распространены, например, в астрономических исследованиях. Добавление примеси (As, Ga, Sb) ведёт к замещению одного из атомов германия в кристаллической решетке на атом примеси, причем ее электроны образуют водородоподобную модель. Исследование такой модели интересно как в рамках фундаментальной науки, так и для применений.

Времена релаксации возбужденных состояний примеси в германии при низких температурах лежат в терагерцовой области спектра. Для их измерения была применена система «накачка-зондирование», с использованием Новосибирского лазера на свободных электронах (ЛСЭ) как источника излучения. Новосибирский ЛСЭ генерирует монохроматическое излучение с перестраиваемой длиной волны в диапазоне 5-240 мкм.

В основе принципа «накачка-зондирование» лежит разделение лазерного пучка на более мощный импульс накачки, который возбуждает определенный энергетический переход в образце, и на импульс зондирования, который проходит через оптическую задержку и детектирует временную характеристику прозрачности образца. Образец, германий допированный мышьяком, был помещён в проточный гелиевый криостат и имел температуру 4К. На время прохождения импульса ЛСЭ длительностью 100 пс образец становился прозрачным, т.к. носители примеси переходят в возбужденное состояние. Далее его прозрачность уменьшалась пропорционально релаксации носителей заряда. На Рисунке 1 показана зависимость сигнала от времени задержки при разных мощностях. Видно, что сигнал хорошо описывается экспоненциальной функцией. В таком случае показатель экспоненты соответствует времени релаксации соответствующего энергетического перехода. 


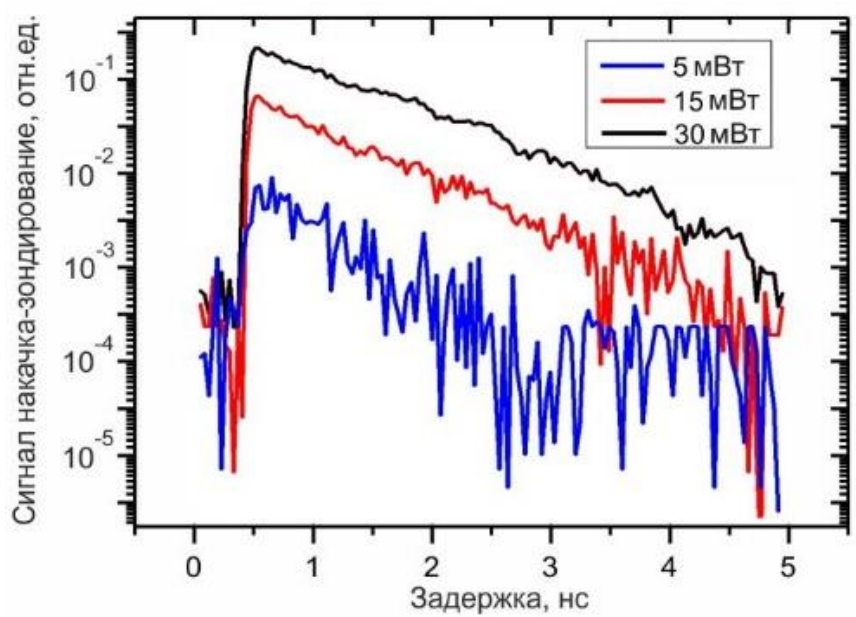

Рис. 1. Зависимость мощности сигнала в канале зондирования от времени задержки. $\mathrm{P}_{\text {зондирования }}=0,8$ мВт, $\lambda=140$ мкм, Т=4К.

В качестве детектора был использован оптоакустический детектор ячейка Голея. Для увеличения соотношения сигнал/шум была применена синхронная схема детектирования с частотой 15 Гц, которая обусловлена максимальной чувствительностью ячейки Голея.

В докладе будут представлены результаты исследований релаксационной динамики возбужденных носителей в n-Ge:As. 